DOI https://doi.org/10.30525/978-9934-26-074-2-46

\title{
ІСТОРИЧНІ ЕТАПИ СТАНОВЛЕННЯ ТА РОЗВИТКУ КРИМІНАЛЬНОГО ПРАВА УКРАЇНИ
}

\author{
Денисов Г. О. \\ студент I курсу юридичного факультету \\ Науковий керівник: Сисоєва В. П. \\ дочент кафедри кримінального права і процесу \\ юридичного факультету \\ Національного авіаційного університету \\ м. Київ, Украӥна
}

Дослідження історії українського кримінального права є важливим напрямом сучасної вітчизняної кримінально-правової доктрини, його актуальність полягає у доведенні безперервності боротьби суспільства та держави із злочинністю в усіх іiї проявах в різні історичні етапи.

Процес зародження вітчизняного кримінального права тривав впродовж більш як половину тисячоліття - від перших зародків державності у східних слов'ян i, принаймні, до ХІ століття. Будучи усним звичаєвим, тогочасне право не знало жодних форм систематизації, а тим більше поділу на галузі. Тогочасне кримінальне право мало виражений релігійний характер: злочин вважався різновидом гріха, а покарання священним обов'язком племені. Згодом кримінальні норми запозичувалися Руссю із візантійських правових збірників, зміст яких певним впливом позначається на розвитку законодавства. Кримінально-правові норми продукувалися в ході законодавчої діяльності київських князів (княжі та церковні устави) також значною мірою під впливом візантійської правової традиції та місцевих звичаєво-правових норм. У сучасній науці історії держави і права України утвердилася думка про те, що в цілому розвиток права на Русі здійснювався у напрямку створення норм, які поширювали чи змінювали звичаєві традиції і за своєю формою мало чим від них відрізнялися. Яскравий приклад цьому - «Руська правда» [1, с. 3-4].

Варто виділити такі характерні риси розвитку кримінального права Київської Русі: карне право князівського періоду пройшло певну еволюцію від приватного карного права, коли реакція на злочин $\mathrm{i}$ судочинство належали самому скривдженому шляхом помсти (таліону) та викупів (компенсації) до публічного права і державного судочинства у вигляді державних кар та їх комбінацій; об'єктом і суб'єктами злочинів визнавалися лише вільні люди; відсутність дефініції самого злочину. Під 178 
злочином «Руська правда» розуміла «обіду», «кривду» (канонічне право «гріх»). Першим відомим кодифікованим збірником давньоруських юридичних норм стала «Руська правда». В ній були виділені такі види злочинів: 1) проти життя (ненавмисне і навмисне убивство, або розбій, з наміром і без наміру); 2) проти тіла (каліцтво, тяжкі тілесні ушкодження, побої); 3) проти честі і свободи (удар мечем у піхвах або рукояткою); 4) проти майна (крадіжка, або татьба, грабунок, чи розбій, привласнення чужого майна, пошкодження чужої власності, розорення межі чи пошкодження межового знака, підпал, шахрайство, конокрадство); 5) проти громадських інтересів: а) проти релігії (чарівництво, волхвування, богохульство); б) проти родини (двоєженство та кровомішання, перелюбство); в) проти моралі (згвалтування, статеві збочення); 6) злочини проти держави. Варто звернути увагу також на те, що в Руській правді не було покарання у виді смертної кари, хоча можна було вбити злочинця на місці злодіяння [2, с.52].

У Великому князівстві Литовському, до складу якого з середини XIV ст. входила значна частина проукраїнських земель, застосовувалися положення «Руської Правди», литовці на землях Русі дотримувалися принципу «Старини не рушити, новини - не вводити». Потреба в удосконаленні законодавства виникла лише в XV ст. Вона була втілена Великим князем Литовським Казимиром Ягайловичем в 1468 р. шляхом прийняття Судебника. В 1529 р. було укладено перший фундаментальний комплексний правовий акт - Перший «Литовський Статут», до складу якого входили 9 груп складу злочинів. Кожний склад злочину традиційно мав у своїй структурі систему об'єктивних і суб'єктивних ознак та санкції, чітко вибудувану систему видів покарань. Редакція цього Статуту удосконалювалася в 1566 та 1588 pp. В останньому 3 названих років вперше було сформульовано принцип верховенства закону, реально діяв принцип гуманізму, допускалася заміна смертної кари позбавленням честі [2, с. 80-81].

Найвідомішою 3 кодифікацій українського кримінального права Української гетьманської держави першої половини XVIII ст. були «Права, по которым судится малороссийский народ» (1743) р., у якому крім інших положень було сформовано 8 сталих груп складу злочинів. У ньому вперше були закріплені норми, спрямовані на кримінально-правову охорону особи російського монарха-самодержця в період його перебування на території Гетьманщини, ця особливість обумовлювалася більшою жорстокістю політичного режиму, який існував в Україні під час іiї перебування під протекторатом Російської імперії [там само, с. 133-134]. 
На етнічних українських землях, що входили до складу Російської імперії в другій половині XIX - на початку XX століття, розвиток права здійснювався у напрямку інкорпорації попередньої правової системи у загальноімперську. I якщо у сфері цивільно-правового регулювання самодержавство допускало урахування місцевих особливостей (Полтавська й Чернігівська губернії), то норми кримінального права якраз найменше враховували існуючі в російській Україні регіональні особливості. Кодифікація кримінального права як галузі у Російській імперії розпочалася лише з укладенням Зводу законів Російської імперії (1832 р.), у якому кримінальним нормам відвели 15 том. Важливе місце в системі джерел кримінального права в Росії відводилося Уложенню про покарання кримінальні й виправні 1845 р. (зі змінами і доповненнями у редакції 1885 року). У ньому злочинні дії поділялися на тяжкі злочини, злочини і проступки, за вчинення яких передбачалося 35 видів покарання - від осуду до смертної кари.

Пізніше, з початку XX століття, основним джерелом кримінального права Російської імперії було «Кримінальне уложення» (1903р.), підписане імператором Миколою II. Кримінальне уложення поділяло злочинні діяння на три групи: тяжкі злочини (за них призначалися: смертна кара, каторга або заслання), злочини (каралися ув'язненням) та проступки (арешт або грошовий штраф). Покарання поділялися на головні (смертна кара, каторга, заслання, ув'язнення), додаткові (позбавлення прав стану, права займатися певними видами діяльності чи обіймали певні посади) й замінні. При визначенні покарання суд враховував станову належність злочинця і потерпілого. Смертна кара, що виконувалася публічно через повішення, не застосовувалася до осіб молодших за 17 і старших 70 років [1, с. 33-34].

Становлення і розвиток в Україні радянського кримінального права починається з так званого декретного періоду, а саме - прийняттям в Росії у грудні 1919 року «Керівних начал з кримінального права РСФРР» (офіційно введені у дію на території України 4 серпня 1920 р.). Російські «Керівні начала» (1919р.), а також прийняті урядом УСРР впродовж 1921 р. нормативні акти, що спрямовувалися на боротьбу з бандитизмом (постанова «Про заходи боротьби з бандитизмом»), посадовими злочинами (постанова «Про заходи боротьби 3 посадовими злочинами»), хабарництвом (постанова «Про боротьбу з хабарництвом») стали основою для створення Кримінального кодексу УСРР - єдиного нормативного акта, який би відображав державну кримінально-правову політику [1, с. 57]. Пізніше, кримінальний кодекс редакції 1922 р. вже був прототипом сучасного кримінального законодавства: серед іншого, він складався із загальної та особливої частин. Проте диктаторські 
схильності радянської влади призвели до посилення кримінальної репресії шляхом внесення змін до цього кодексу (кримінальний кодекс УСРР редакції 1927 р.), яке, зокрема, передбачало можливість застосування кримінальної репресії за вчинення діянь без вини; можливість застосування аналогії кримінального закону, яка розв'язувала руки виконавцям політики терору тощо.

Кримінальний кодекс редакції 1960 р. був спрямований на посилення кримінальної відповідальності за посягання на державний та суспільний лад. Ключовими положеннями цього КК УРСР були, наприклад, заборона аналогії в кримінальному праві; зменшення кількості діянь (бездіяльності), які раніше кваліфікувались злочинними; зменшення максимального терміну позбавлення волі з 25 до 15 років; скорочення переліку покарань, збільшення віку, з якого може наставати кримінальна відповідальність 316 років, а за вчинення особливо тяжких злочинів з 14 років, без застосування смертної кари (розстрілу), яка призначалась лише за злочини проти держави; водночас, посилилась відповідальність за рецидивні злочини, фальшування грошей, крадіжки державного майна у великих розмірах, згвалтування, хабарництво, посягання на життя працівника міліції, заподіяння злочином особливо великих збитків державі, суспільству, особі [2, с. 271-273].

Від часу здобуття незалежності впродовж наступних 10 років в Україні діяло пристосоване до нових реалій кримінальне законодавство колишньої УРСР [1, с. 83]. Слід зазначити, що чинний КК України редакції 2001 р. у незмінному вигляді містив лише 28 статей, які були також в КК УРСР редакції 1960 р. У цілому окремі запозичення становлять 17\% від усієї чисельності статей. Чинний КК України, на відміну від КК УРСР редакції 1960 р., що розрізняв відповідальність за злочини проти державної, колективної та індивідуальної власності, містить лише один розділ - злочини проти власності. Крім цього, КК України редакції 2001 р. було приведено у відповідність до загальноприйнятих норм міжнародного права [2, с. 297].

Розглядаючи історію розвитку та становлення кримінального права, слід зазначити, що воно має генетичний зв'язок із сучасним кримінальним законодавством України, також воно має істотне значення для науки, бо історія розвитку кримінального права як безпосередньої складової кримінального права, дає розуміння сучасного стану, тенденцій і перспектив розвитку кримінального законодавства в Україні. 3 огляду на це можна побудувати структуровану система подальшого розвитку кримінального права України на принципах міжнародного співробітництва, і доведення проекту нового кримінального кодексу України до європейських стандартів. 


\title{
Література:
}

1. Терлюк I. Я. Огляд історії кримінального права України : навчальний посібник. Львів: Ліга-Прес, 2007. 92 с.

2. Ухач В. 3. Історія держави і права України : навчальний посібник (конспекти лекцій). Тернопіль: Вектор, 2011.378 с.

DOI https://doi.org/10.30525/978-9934-26-074-2-47

\section{ПРОБЛЕМНІ ПИТАННЯ РОЗВИТКУ КРИМІНАЛЬНОГО ЗАКОНОДАВСТВА У СФЕРІ ПРОТИДІЇ БУЛІНГУ}

\author{
Ільїна О. В. \\ кандидат юридичних наук, доиент, \\ дочент кафедри кримінально-правової політики \\ та кримінального права \\ Київського начіонального університету імені Тараса Шевченка \\ м. Київ, Украӥна
}

Конституція України проголосила «людину, іiі життя і здоров’я, честь і гідність, недоторканність і безпека найвищою соціальною цінністю. Права і свободи людини та їх гарантії визначають зміст і спрямованість діяльності держави. Держава відповідає перед людиною за свою діяльність. Утвердження і забезпечення прав і свобод людини є головним обов'язком держави» (ст. 3) [1]. Оскільки Конституція України має свою силу на всій території України та стосується всіх ії̈ громадян, можна 3 упевненістю сказати, що людина як найвища соціальна цінність має захищатися у всіх сферах ії життя: побутовому, соціальному, правовому. Що стосується соціального життя людини та ії комунікацій з іншими особами, вважаємо за необхідне згадати ст. 28 Основного Закону: «кожен має право на повагу до його гідності. Ніхто не може бути підданий катуванню, жорстокому, нелюдському або такому, що принижує його гідність, поводженню чи покаранню [1]. Цитована стаття набуває особливого значення в сучасних умовах підвищення рівня підліткової агресії. Вчені наводять статистику, що «за даними Всесвітньої організації охорони здоров'я, Україна посідає четверте місце в світі за рівнем підліткової агресії, поступаючись лише Росії, Албанії та Білорусі» [2, с. 107].

Звертаючись до тлумачення терміну «булінг», вчені визначають, що він означає «цькування, залякування, агресивне переслідування одного 3 членів колективу з боку інших представників колективу» [2, с. 108]. «Булінг може проявлятись у вигляді психологічного тиску (образи, 182 